\title{
Genetic Studies on Charcoal Rot Resistance in Minicore Collection of Sorghum during Rabi Season
}

\author{
V. Nagamani* and B.D. Biradar \\ Department of Genetics and Plant breeding, College of Agriculture, UAS, \\ Dharwad-580005, Karnataka, India \\ *Corresponding author
}

\begin{tabular}{|c|}
\hline Keywords \\
\hline $\begin{array}{l}\text { Sorghum, Correlation, } \\
\text { Charcoal rot, } \\
\text { Heritability, Genetic } \\
\text { advance }\end{array}$ \\
\hline Article Info \\
\hline $\begin{array}{l}\text { Accepted: } \\
\text { 10 February } 2018 \\
\text { Available Online: } \\
10 \text { March } 2018\end{array}$ \\
\hline
\end{tabular}

\section{Introduction}

Sorghum [Sorghum bicolor (L.) Moench] $(2 \mathrm{n}=2 \mathrm{x}=20$, family Poaceae) is an important grain and fodder crop. It is the fifth most important cereal crop world-wide after wheat, maize, rice and barley. It is grown in about 90 countries over an area of about 41.0 million hectare with production of 64.16 million tonnes of grain and having a productivity of $1600 \mathrm{~kg}$ per hectare. In India, sorghum ranks fourth as food and first as forage. It is grown over an area 5.5 million hectare with the production of 5.0 million tonnes and
Genetic variability, heritability, genetic advance and correlation were estimated for charcoal rot component traits, yield and its component traits. High values of PCV and GCV were observed for majority of traits, indicating a greater scope for improvement of these traits. High heritability coupled with high genetic advance over mean was observed for majority of traits, indicating these characters would be more effective for further improvement through simple selection. Significant and negative association of lodging per cent with grain and fodder yield indicated lodging affects grain yield and fodder yield. The association between stay green and charcoal rot parameters was negative indicating stay green types are tolerant to charcoal rot. Brix percentage recorded significant negative correlation with charcoal rot parameters. Stem girth exhibited significant positive associon with number of leaves per plant, spreading of fungus and fodder yield per plot. Based on these results it could be concluded that, to enhance fodder yield and quality, the breeder need to focus on medium thick stem, more number of leaves, higher chlorophyll content at flag leaf and at maturity and high brix percentage. These traits would reduce the charcoal rot disease there by enhancing quality and quantity of the fodder and grain. 
Improved, high-yielding cultivars under good management tend to be very susceptible to the disease (Mughogho and Pande, 1984). Drought stress is the primary factor that predisposes sorghum to charcoal rot.

Since sorghum being a poor man crop, identification of durable resistance becomes a viable alternative in the management of the charcoal rot disease. Thus the present study was undertaken with an aim to identify the genotype with high grain yielding, charcoal rot resistance coupled with high fodder yield.

\section{Materials and Methods}

The experiment was carried out at Botany garden, Department of Genetics and Plant Breeding, Main Agricultural Research Station, University of Agricultural Sciences, Dharwad during rabi2016-17. It involves 236 sorghum minicore accessions and four checks. This material was used for the field evaluation of charcoal rot disease, yield and their component traits.

Experiment was laid out in Randomized Complete Block Design (RCBD) and sowing was done during second week of October (rabi season of 2016-17). The trial was laid out with a spacing of $45 \times 15 \mathrm{~cm}$ and other recommended packages of practices were followed to raise a good crop. To create epiphytotic conditions for charcoal rot incidence, tooth pick method (Edmunds, 1964) was employed. In tooth pick method, individual plants were inoculated with Macrophomina phaseolina cultured on tooth picks in honey peptone medium after 15 days of flowering of genotype.

The observations were recorded on disease parameters viz., spreading of fungus, number of internodes crossed by fungus, per cent lodging, per cent disease incidence, days to 50 per cent flowering, days to maturity, plant height, panicle length, panicle width, 100-seed weight, number of primaries per panicle, panicle weight, chlorophyll content at flag leaf stage, chlorophyll content at maturity stage, stem girth, brix per cent at maturity, number of leaves per plant, fodder yield per plot and grain yield per plant were recorded on five randomly selected competitive plants leaving border plants of each row.

\section{Statistical analysis}

Analysis of variance was carried out following the standard procedures. The phenotypic and genotypic coefficients of variability (PCV, GCV) were computed according to the method suggested by Burton (1952), heritability (Broad sense) and genetic advance as per Johanson et al., (1955). Both genotypic and phenotypic coefficients of variability were computed for each character as per method suggested by Burton and Devane (1953)

\section{Results and Discussion}

The analysis of variance revealed significant differences among the genotypes for all the characters studied (Table 1). Non-significant variation was observed for replication which indicated less influence of environment on the genotypic performance. The estimate of genetic variability parameters indicated wide range of variations for all the characters studied (Table 2). Relative magnitude of PCV was greater than corresponding GCV for all characters studied, which indicated the effects of environmental factors in expression of morphological characters. Both the estimates of variation were within a narrow range for most of the traits which, implied that phenotypic variability can be used as reliable measure of genotypic variability.

High values of GCV and PCV were found for the traits such as length of spread of Mphaseolina, per cent lodging, per cent 
disease incidence, number of internodes crossed by fungus, plant height, panicle length, panicle width, 100-seed weight, panicle weight, number of primaries per panicle, stem girth, chlorophyll content at maturity, brix percentage, fodder yield per plot and grain yield per plant which indicated variation for these characters and their contribution towards total genetic variability. However, moderate values of PCV and GCV observed for traits such as, chlorophyll content at flag leaf stage and number of leaves per plant and indicated that these characters are amenable for improvement. Low estimates of PCV and GCV were recorded for days to 50 per cent flowering and days to maturity in minicore accessions indicating low variability for these traits. The disease parameters of charcoal rot resistance like length of infection and per cent lodging, which have not been studied widely so far, were found to be similar to the report of Patil (2009).

In the present study high estimates of broad sense heritability noticed for majority of the characters viz., length of spread of fungus, per cent lodging, number of internodes crossed by M. phaseolina., per cent disease incidence, plant height, panicle weight, panicle length, panicle width, number of primaries per panicle, numbers of leaves per plant, days to 50 per cent flowering, 100-seed weight, chlorophyll content at flag leaf stage, chlorophyll content at maturity, brix per cent at maturity, fodder yield per plot and grain yield per plant. Moderate heritability was observed for the traits viz., stem girth, days to maturity and fodder yield per plot.

High heritability coupled with high genetic advance over mean was observed for the majority traits studied. This reveals that these characters would respond to the selection as these are more likely to be controlled by additive gene effects. High genetic advance coupled with high heritability estimates offers the most suitable condition for selection Kalpande et al., (2015). High heritability coupled with moderate genetic advance for days to 50 per cent flowering and chlorophyll content at flag leaf stage indicate that these traits are more likely controlled by both additive and non-additive gene actions. The high heritability coupled with low genetic advance for days to maturity indicate that this trait was more likely controlled by nonadditive gene action.

Girish et al., (2016) reported high heritability along with high genetic advance over mean for length of spread of fungus, per cent lodging, number of internodes crossed by fungus and seed yield.

Among the charcoal rot parameters per cent lodging found to be positively associated with numbers of internode crossed, length of spreading of the fungus as well as other agronomical trait viz., plant height. This indicates that spread of the fungus and more number of internodes crossed weakens the stem at the base. This coupled with tallness enhance lodging and affect the total fodder quality. Hence, a combination of medium height, medium thick stem, large panicle and resistance to charcoal rot disease are desirable traits in productive genotypes. The significant negative association of per cent lodging with grain yield per plant was observed.

Among yield component traits the perusal of phenotypic and genotypic correlation revealed that, grain yield per plant had high positive significant phenotypic and genotypic correlation with panicle weight, plant height, 100 -seed weight, number of primaries per panicle and 50 per cent flowering indicating grain yield is largely a function of these five attributes and the importance may be given for these traits in yield improvement programme. Similar results were reported by Mahajan et al., (2011). 
Table.1 Mean sum of squares of sorghum minicore accessions for charcoal rot, grain yield and their component traits

\begin{tabular}{l|}
\hline Components \\
\hline Degrees of freedom \\
\hline Lodging percentage \\
\hline Spread of fungus (cm) \\
\hline Number of internodes crossed \\
\hline Percent incidence \\
\hline Days to 50 \% flowering \\
\hline Days to maturity \\
\hline Plant height (cm) \\
\hline Earhead length (cm) \\
\hline 100 seed weight (g) \\
\hline Number of primaries per panicle \\
\hline Earhead width (cm) \\
\hline Panicle weight (g) \\
\hline SPAD value at flag leaf stage \\
\hline SPAD value at maturity stage \\
\hline Stem girth (cm) \\
\hline Brix \% at maturity \\
\hline Number of leaves per plant \\
\hline Fodder yield per plot (kg) \\
\hline Grain yield per plant (g) \\
\hline
\end{tabular}

\begin{tabular}{|l|l|l|l|l|l|l|}
\hline Replication & Genotypes & Error & S. Em. \pm & $\begin{array}{l}\text { C. D. at } \\
5 \%\end{array}$ & $\begin{array}{l}\text { C. D. } \\
\text { at } \mathbf{\%}\end{array}$ & \\
\hline 1 & 236 & 236 & - & - & - & - \\
\hline 63.87 & $1810.3^{*}$ & 20.94 & 3.220 & 9.010 & 11.80 & 16.22 \\
\hline 4.480 & $1992.8^{*}$ & 3.910 & 1.390 & 3.890 & 5.130 & 5.290 \\
\hline 1.400 & $4.72^{*}$ & 0.160 & 0.280 & 0.790 & 1.040 & 17.67 \\
\hline 274.9 & $1698.3^{*}$ & 120.5 & 7.740 & 21.63 & 28.50 & 16.66 \\
\hline 222.8 & $122.13^{*}$ & 28.07 & 3.730 & 10.43 & 13.75 & 7.340 \\
\hline 236.3 & $207.84^{*}$ & 68.56 & 5.840 & 16.31 & 21.50 & 6.200 \\
\hline 393.2 & $3199.86^{*}$ & 216.15 & 10.37 & 28.96 & 38.17 & 7.640 \\
\hline 10.06 & $77.75^{*}$ & 9.740 & 2.200 & 6.140 & 8.100 & 14.62 \\
\hline 0.550 & $1.180^{*}$ & 0.140 & 0.270 & 0.760 & 1.000 & 11.78 \\
\hline 35.65 & $314.06^{*}$ & 13.48 & 2.590 & 7.230 & 9.530 & 8.290 \\
\hline 1.850 & $7.070^{*}$ & 0.560 & 0.530 & 1.480 & 1.950 & 10.64 \\
\hline 25.00 & $989.9^{*}$ & 13.94 & 2.630 & 7.350 & 9.690 & 7.620 \\
\hline 41.97 & $86.10^{*}$ & 16.48 & 2.860 & 7.990 & 10.54 & 7.670 \\
\hline 38.37 & $317.39^{*}$ & 13.10 & 2.550 & 7.130 & 9.390 & 13.80 \\
\hline 0.090 & $0.190^{*}$ & 0.030 & 0.120 & 0.350 & 0.460 & 13.49 \\
\hline 3.360 & $63.03^{*}$ & 1.500 & 0.860 & 2.410 & 3.180 & 12.59 \\
\hline 1.020 & $4.450^{*}$ & 0.750 & 0.610 & 1.710 & 2.260 & 11.54 \\
\hline 0.008 & $0.170^{*}$ & 0.003 & 0.040 & 0.110 & 0.140 & 13.65 \\
\hline 21.45 & $671.8^{*}$ & 32.16 & 4.000 & 11.17 & 14.72 & 14.79 \\
\hline
\end{tabular}

$*_{\text {-Significant at } 5 \% \text { level }}$

Table.2 Estimates of genetic variability parameters in sorghum minicore accessions for charcoal rot, yield and their component traits

\begin{tabular}{|l|}
\hline Traits \\
\hline Spread of fungus (cm) \\
\hline Number of internodes crossed \\
\hline Per cent lodging \\
\hline Per cent incidence \\
\hline Days to 50 \% flowering \\
\hline Days to maturity \\
\hline Plant height (cm) \\
\hline Earhead length (cm) \\
\hline 100 seed weight (g) \\
\hline Number of primaries per panicle \\
\hline Earhead width (cm) \\
\hline Earhead weight (g) \\
\hline SPAD value at flag leaf stage \\
\hline SPAD value at maturity stage \\
\hline Stem girth (cm) \\
\hline Brix per cent at maturity \\
\hline Number of leaves per plant \\
\hline Fodder yield per plot (kg) \\
\hline Grain yield per plant (g) \\
\hline
\end{tabular}

\begin{tabular}{|l|l|l|}
\hline Range & Grand \\
\hline Minimum & Maximum & 37.39 \\
\hline 0.000 & 138.0 & 2.26 \\
\hline 0.000 & 7.040 & 28.35 \\
\hline 0.000 & 100.0 & 63.74 \\
\hline 0.000 & 100.0 & 72.10 \\
\hline 54.50 & 98.00 & 133.5 \\
\hline 110.0 & 158.0 & 192.3 \\
\hline 87.60 & 328.1 & 21.33 \\
\hline 6.400 & 51.00 & 3.27 \\
\hline 1.450 & 5.71 & 44.27 \\
\hline 19.00 & 87.75 & 7.07 \\
\hline 2.320 & 14.00 & 48.97 \\
\hline 10.10 & 154.8 & 50.82 \\
\hline 35.01 & 61.19 & 26.21 \\
\hline 5.880 & 57.90 & 1.32 \\
\hline 0.500 & 2.430 & 9.73 \\
\hline 0.200 & 28.00 & 7.54 \\
\hline 3.830 & 13.00 & 0.42 \\
\hline 0.100 & 1.530 & 38.34 \\
\hline 8.400 & 132.4 & \\
\hline
\end{tabular}

\begin{tabular}{|l|}
\hline PCV \\
\hline \%) \\
\hline 84.50 \\
\hline 68.90 \\
\hline 106.7 \\
\hline 47.30 \\
\hline 12.01 \\
\hline 8.80 \\
\hline 21.49 \\
\hline 31.00 \\
\hline 24.89 \\
\hline 28.90 \\
\hline 27.63 \\
\hline 45.74 \\
\hline 13.53 \\
\hline 49.03 \\
\hline 25.41 \\
\hline 58.37 \\
\hline 21.38 \\
\hline 69.88 \\
\hline 48.99 \\
\hline
\end{tabular}

\begin{tabular}{|l|l|l|l|}
\hline $\begin{array}{l}\text { GCV } \\
(\%)\end{array}$ & $\begin{array}{l}\text { Heritability } \\
(\%)\end{array}$ & $\begin{array}{l}\text { Genetic } \\
\text { advance }\end{array}$ & $\begin{array}{l}\text { GA as \% of } \\
\text { mean }\end{array}$ \\
\hline 84.33 & 99.61 & 65.10 & 173.4 \\
\hline 66.59 & 93.42 & 3.020 & 132.6 \\
\hline 105.5 & 97.71 & 61.22 & 214.8 \\
\hline 44.06 & 86.74 & 53.70 & 84.53 \\
\hline 9.51 & 62.62 & 11.16 & 15.50 \\
\hline 6.25 & 50.39 & 11.51 & 9.14 \\
\hline 20.09 & 87.34 & 74.29 & 38.67 \\
\hline 27.33 & 77.74 & 10.63 & 49.64 \\
\hline 21.92 & 77.59 & 1.29 & 39.78 \\
\hline 27.69 & 91.76 & 23.99 & 54.64 \\
\hline 25.50 & 85.17 & 3.004 & 48.48 \\
\hline 45.10 & 97.22 & 44.93 & 91.61 \\
\hline 11.14 & 67.86 & 10.04 & 18.91 \\
\hline 47.05 & 92.07 & 24.48 & 93.00 \\
\hline 21.54 & 71.82 & 0.407 & 37.60 \\
\hline 56.99 & 95.34 & 11.22 & 114.6 \\
\hline 18.00 & 70.78 & 2.363 & 31.22 \\
\hline 68.53 & 96.18 & 0.564 & 138.5 \\
\hline 46.71 & 90.89 & 35.07 & 91.73 \\
\hline
\end{tabular}


Table.3 Estimates of phenotypic correlation coefficients for charcoal rot, yield and its component traits in Sorghum minicore accessions

\begin{tabular}{|c|c|c|c|c|c|c|c|c|c|c|c|c|c|c|c|c|c|c|c|}
\hline Traits & SP & NIC & LD \% & PDI & DFF & DM & PH & PL & HSW & NPP & PW & PWE & SPAD1 & SPAD2 & SG & TSS & NL & FY & GYP \\
\hline SP & 1.00 & $0.76 * *$ & 0.05 & $0.46^{* *}$ & 0.02 & 0.05 & $0.14 * *$ & $0.10^{*}$ & 0.07 & -0.01 & 0.08 & $0.10 *$ & 0.01 & -0.02 & $0.12 * *$ & $-0.12 * *$ & 0.05 & -0.05 & $0.12 *$ \\
\hline NIC & & 1.00 & $0.09 *$ & $0.49 * *$ & 0.03 & 0.01 & 0.055 & 0.03 & -0.03 & -0.002 & 0.03 & 0.05 & -0.03 & -0.06 & 0.06 & $-0.11 * *$ & 0.05 & -0.07 & 0.04 \\
\hline LD \% & & & 1.00 & -0.03 & $-0.15^{* *}$ & -0.09 & $0.12 * *$ & 0.08 & $-0.19 * *$ & -0.02 & -0.08 & $-0.20 * *$ & -0.04 & -0.04 & -0.07 & $-0.19 * *$ & $-0.19 * *$ & $-0.12 * *$ & $-0.24 * *$ \\
\hline PDI & & & & 1.00 & -0.03 & 0.07 & 0.07 & 0.06 & 0.07 & -0.002 & -0.04 & $0.11 *$ & -0.01 & -0.06 & 0.03 & 0.01 & -0.07 & -0.07 & $0.11 *$ \\
\hline DFF & & & & & 1.00 & 0.04 & $0.12 * *$ & -0.03 & -0.04 & 0.04 & -0.002 & $0.19 * *$ & -0.15 & 0.03 & $0.18 * *$ & 0.01 & $0.25 * *$ & $0.11 *$ & $0.10^{*}$ \\
\hline DM & & & & & & 1.00 & -0.07 & -0.01 & 0.01 & -0.04 & -0.01 & -0.001 & -0.05 & 0.04 & 0.08 & 0.05 & -0.06 & -0.06 & -0.02 \\
\hline PH & & & & & & & 1.00 & $0.34 * *$ & $0.13 *$ & $0.15^{* *}$ & $0.19 * *$ & $0.42 * *$ & 0.01 & 0.01 & $0.24 * *$ & -0.01 & $0.60 * *$ & $0.14 * *$ & $0.32 * *$ \\
\hline PL & & & & & & & & 1.00 & $-0.09 *$ & -0.09 & $0.19 * *$ & $0.09 *$ & $0.12 *$ & 0.07 & $0.12 * *$ & $-0.11 *$ & 0.06 & -0.05 & 0.05 \\
\hline HSW & & & & & & & & & 1.00 & 0.05 & 0.09 & $0.32 * *$ & $0.10 *$ & 0.07 & 0.06 & 0.04 & $0.09 *$ & -0.03 & $0.38 * *$ \\
\hline NPP & & & & & & & & & & 1.00 & 0.04 & $0.30 * *$ & -0.01 & 0.02 & $0.09 *$ & -0.07 & $0.16 * *$ & $0.17 * *$ & $0.28 * *$ \\
\hline PW & & & & & & & & & & & 1.00 & 0.08 & -0.05 & 0.04 & 0.09 & -0.01 & $0.14 * *$ & -0.06 & 0.08 \\
\hline PWE & & & & & & & & & & & & 1.00 & $0.19 * *$ & $0.14 * *$ & $0.40 * *$ & $-0.11 *$ & $0.43 * *$ & $0.17 * *$ & $0.84 * *$ \\
\hline SPAD1 & & & & & & & & & & & & & 1.00 & $0.36^{* *}$ & 0.02 & $-0.11 *$ & -0.02 & 0.06 & $0.21 * *$ \\
\hline SPAD2 & & & & & & & & & & & & & & 1.00 & 0.07 & -0.07 & 0.06 & $0.13^{*}$ & $0.09 *$ \\
\hline SG & & & & & & & & & & & & & & & 1.00 & $-0.10^{*}$ & $0.18 * *$ & $0.09 *$ & $0.33 * *$ \\
\hline TSS & & & & & & & & & & & & & & & & 1.00 & -0.03 & 0.01 & -0.06 \\
\hline NL & & & & & & & & & & & & & & & & & 1.00 & $0.21 * *$ & $0.34 * *$ \\
\hline FY & & & & & & & & & & & & & & & & & & 1.00 & $0.18 * *$ \\
\hline
\end{tabular}

Where, SP- length of spread of infection by fungus, NIC- number of internodes crossed by fungus, LD \%- percent lodging, PDI- per cent disease incidence, DFFdays to 50 per cent flowering, DM- days to maturity, PH- plant height,, PL- panicle length, HSW-100 seed weight, NPP- number of primaries per panicle, PWpanicle width, PWE- panicle weight, SPAD1- chlorophyll content at flag leaf stage, SPAD 2- chlorophyll content at maturity, SG- Stem girth, TSS- Total soluble solids at maturity, NL- Number of leaves per plant, FY- Fodder yield per plot and GYP- grain yield per plant. Where,

$*$,** indicates significant at 5 per cent and 1 per cent level of probability, respectively 
Table.4 Estimates of genotypic correlation coefficients for charcoal rot, yield and its component traits in sorghum minicore accessions

\begin{tabular}{|c|c|c|c|c|c|c|c|c|c|c|c|c|c|c|c|c|c|c|c|}
\hline Traits & SP & NIC & LD \% & PDI & DFF & DM & PH & PL & HSW & NPP & PW & PWE & SPAD1 & SPAD2 & SG & TSS & NL & FY & GYP \\
\hline SP & 1.00 & $0.79 * *$ & 0.05 & $0.49^{* *}$ & 0.02 & 0.07 & $0.15^{* *}$ & $0.11^{*}$ & 0.08 & -0.01 & 0.08 & $0.10^{*}$ & 0.01 & -0.02 & $0.15^{* * *}$ & $-0.13^{* *}$ & 0.06 & -0.05 & 0.12 ** \\
\hline NIC & & 1.00 & $0.10^{*}$ & $0.55^{* *}$ & 0.03 & 0.02 & 0.07 & 0.03 & -0.02 & 0.00 & 0.03 & 0.06 & -0.03 & -0.07 & $0.09^{*}$ & $-0.13^{* *}$ & 0.05 & -0.07 & 0.05 \\
\hline LD \% & & & 1.00 & -0.02 & $-0.18^{* *}$ & $-0.12 * *$ & $0.13^{* *}$ & 0.01 & $-0.22 * *$ & -0.02 & -0.09 & $-0.21 * *$ & -0.04 & -0.04 & -0.08 & $-0.19 * *$ & $-0.23 * *$ & $-0.12^{* *}$ & $-0.25^{* *}$ \\
\hline PDI & & & & 1.00 & -0.08 & $0.13^{* *}$ & $0.08^{*}$ & 0.08 & 0.09 & -0.02 & -0.02 & $0.11^{* *}$ & 0.00 & -0.07 & 0.06 & 0.01 & -0.07 & -0.06 & $0.12^{* *}$ \\
\hline DFF & & & & & 1.00 & 0.03 & $0.15^{* *}$ & -0.07 & -0.06 & 0.07 & 0.03 & $0.22 * *$ & $-0.17^{* *}$ & 0.04 & $0.30^{* * *}$ & 0.01 & $0.37^{* *}$ & $0.14 * *$ & $0.11^{* *}$ \\
\hline DM & & & & & & 1.00 & -0.06 & -0.03 & 0.01 & -0.07 & $-0.01 * *$ & -0.02 & -0.01 & 0.07 & 0.09 & 0.08 & -0.11 & -0.07 & -0.01 \\
\hline PH & & & & & & & 1.00 & $0.42 * *$ & $0.16 * *$ & $0.17 * *$ & $0.22 * *$ & $0.46^{* *}$ & 0.02 & 0.01 & $0.32 * *$ & -0.02 & $0.73^{* *}$ & $0.15^{* *}$ & $0.35^{* * *}$ \\
\hline PL & & & & & & & & 1.00 & $-0.13^{* *}$ & -0.08 & $0.24^{*}$ & $0.10^{*}$ & $0.16^{* *}$ & 0.06 & $0.15^{* *}$ & $-0.13^{* *}$ & $0.10^{* *}$ & -0.05 & 0.04 \\
\hline HSW & & & & & & & & & 1.00 & 0.06 & $0.14^{*}$ & $0.36^{* *}$ & $0.14 * *$ & 0.08 & 0.08 & 0.05 & $0.12^{* *}$ & -0.04 & $0.44 * *$ \\
\hline NPP & & & & & & & & & & 1.00 & 0.05 & $0.32 * *$ & 0.00 & 0.02 & $0.14^{* *}$ & -0.07 & $0.20^{* *}$ & $0.17 * *$ & $0.31^{* *}$ \\
\hline PW & & & & & & & & & & & 1.00 & 0.08 & -0.07 & 0.02 & 0.09 & -0.02 & $0.15^{* *}$ & -0.07 & $0.09 *$ \\
\hline PWE & & & & & & & & & & & & 1.00 & $0.24 * *$ & $0.14^{* *}$ & $0.53^{* *}$ & $-0.11 * *$ & $0.50 * *$ & $0.18^{* *}$ & $0.86^{* * *}$ \\
\hline SPAD1 & & & & & & & & & & & & & 1.00 & $0.46^{* *}$ & 0.06 & $-0.13 * *$ & -0.04 & 0.07 & $0.29 * *$ \\
\hline SPAD2 & & & & & & & & & & & & & & 1.00 & 0.07 & -0.08 & 0.07 & $0.13 * *$ & $0.10^{* *}$ \\
\hline SG & & & & & & & & & & & & & & & 1.00 & $-0.11 * *$ & $0.31^{* *}$ & $0.11^{* *}$ & $0.44^{* *}$ \\
\hline TSS & & & & & & & & & & & & & & & & 1.00 & -0.04 & 0.02 & -0.07 \\
\hline NL & & & & & & & & & & & & & & & & & 1.00 & $0.26^{* *}$ & $0.40^{* *}$ \\
\hline FY & & & & & & & & & & & & & & & & & & 1.00 & $0.19 * *$ \\
\hline
\end{tabular}

Where, SP- length of spread of infection by fungus, NIC- number of internodes crossed by fungus, LD \%- percent lodging, PDI- per cent disease incidence, DFFdays to 50 per cent flowering, DM- days to maturity, PH- plant height,, PL- panicle length, HSW-100 seed weight, NPP- number of primaries per panicle, PWpanicle width, PWE- panicle weight, SPAD1- chlorophyll content at flag leaf stage, SPAD 2- chlorophyll content at maturity, SG- Stem girth, TSS- Total soluble solids at maturity, NL- Number of leaves per plant, FY- Fodder yield per plot and GYP- grain yield per plant. Where,

*, ** indicates significant at 5 per cent and 1 per cent level of probability, respectively. 
Table.5 List of superior genotypes identified across the traits studied

\begin{tabular}{|c|c|c|}
\hline Sl. No & Accessions & Characters \\
\hline 1 & IS7987 & $\begin{array}{l}\text { Panicle weight, grain yield per plant, stem girth, number of leaves per } \\
\text { plant and resistance to charcoal rot disease }\end{array}$ \\
\hline 2 & IS4360 & $\begin{array}{l}100 \text {-seed weight, earhead weight, grain yield per plant and resistance } \\
\text { to charcoal rot disease. }\end{array}$ \\
\hline 3 & IS14290 & $\begin{array}{l}100 \text { seed weight, earhead weight, grain yield per plant and resistance } \\
\text { to charcoal rot disease. }\end{array}$ \\
\hline 4 & IS23590 & $\begin{array}{l}\text { Days to } 50 \% \text { flowering, number of primaries per panicle and fodder } \\
\text { yield per plot. }\end{array}$ \\
\hline 5 & IS29714 & Days to maturity, earhead width and number of leaves per plant \\
\hline 6 & IS8777 & Plant height, earhead length and number of leaves per plant. \\
\hline 7 & IS12447 & Plant height and fodder yield per plot. \\
\hline 8 & IS6351 & 100 -seed weight and chlorophyll content at maturity. \\
\hline 9 & IS1233 & Grain yield per plant and fodder yield per plot. \\
\hline 10 & IS25836 & Chlorophyll content at flag leaf stage and number of leaves per plant. \\
\hline 11 & IS29241 & Chlorophyll content at maturity and stem girth. \\
\hline 12 & IS24503 & Days to $50 \%$ flowering and earhead length. \\
\hline
\end{tabular}

They reported that grain yield per panicle had showed positive significant association at both phenotypic and genotypic levels with plant height and 100-seed weight.

High positive correlation of plant height with grain as well as fodder yield indicates, it is most important trait in developing dual purpose rabi sorghum cultivars. Earliar workers also opined similarly (Thombre and Patil, 1985; Sankarapandian et al., 1994; Scapim et al., 1998).

In minicore, the association between chlorophyll content and charcoal resistance traits was negative. The results indicate the importance of stay-green in reducing the charcoal rot incidence. Positive and significant association was found between stay-green with 100 seed weight and grain yield. This results was supported by Borrell et al., (2000) and they proclaimed that retention of photosynthetic capacity under waterlimited conditions ensures continued availability of new assimilates and is associated with increased $\mathrm{N}$ uptake during grain filling potentially improving grain size. Hence, stay-green can potentially increase grain yield by enhancing grain filling.

Stem girth exhibited positive and significant association with number of leaves per plant, spreading of fungus and fodder yield per plot at both phenotypic and genotypic level. However, a negative and significant correlation was observed with brix per cent at both phenotypic and genotypic level. There was a highly significant correlation between stem thickness and length of spread of fungus. These association patterns indicate thicker stalks will have less brix, consequently allowing spread of fungus. Hence it is suggested to select for medium thick stem for enhancing fodder yield and quality. Further, these observations are in agreement with Das et al., (2008), where they had observed longer spreading of pathogen in thick-stalked genotypes compared to thinner ones when sorghum genotypes were inoculated with $M$. phaseolina. 
Brix per cent recorded highly significant and negative correlation with chlorophyll content at flag leaf stage, stem girth and disease parameters at both genotypic and phenotypic level. These results indicate quantity of sugar in the stalk appears to have an effect on disease symptoms with higher the sugar content in resistant genotypes than the susceptible ones. Similar results were also reported by Gill et al., (2005) for total soluble sugars. Harleen et al., (2008) suggested that higher protein content, phenols, total sugars and reducing sugars coupled with other biochemical components in cultivars might be responsible for inducing the resistance to charcoal rot.

There was significant and positive correlation observed at both phenotypic and genotypic level for fodder yield per plot with number of leaves per plant, chlorophyll content at maturity stage and stem girth which indicated that these characters are important components of the fodder yield (Table 3 and 4). Hence, selection for these characters will help in selecting genotypes with high fodder yield. Iyanar et al., (2010) observed that fodder yield exhibited high correlation with number of leaves. However, when we scan interrelationship of stem thickness with charcoal rot parameters it is better not to opt for thick stem instead select for thin or medium thick stem.

In the present study, there were many genotypes which were promising across important traits. Among theme IS14290 and IS4360 found significantly superior for 100seed weight, panicle weight, grain yield per plant and also resistant to charcoal rot disease. Similarly IS7987 was superior genotype for panicle weight, grain yield per plant, stem girth, number of leaves per plant and also resistant to charcoal rot. The accession IS1233 was superior for fodder yield per plot and grain yield per plant indicating this could be further evaluated for grain and fodder (dual purpose). Similarly, IS23590 recorded significantly superior for early maturity, number of primaries per panicle, fodder yield per plot and charcoal rot resistance (Table 5).

Overall, based on the present study it could be proclaimed that, to enhance fodder yield and quality, the breeder may have to focus on medium thick stem, more number of leaves, higher chlorophyll content at flag leaf and maturity and high brix percentage. These traits would reduce the charcoal rot disease there by enhancing quality of the fodder.

\section{References}

Anonymous, 2015, Agricultural Statistics at a Glance, 2015. Department of Agricultural and Cooperation, Ministry of Agriculture, Government of India, p. 84.

Borrell, A. K., Hammer, G. L. and Henzell, R. G., 2000. Does maintaining green leaf area in sorghum improve yield under drought II. Dry matter production and yield.Crop Sci., 145-152.

Burton, G. N. and Devane, E. M., 1953, Estimating heritability in fall fescue (Festuca arundiancea L.) from replicated clonal material. Agron. J., 45: 478-481.

Burton, G.W., 1952, Quantitative inheritance in grasses. In: Proceedings 6th International Grassland Congress.1:277283.

Das, I.K., Prabhakar. and Indira, S., 2008, Role of stalk-anatomy and yield parameters in development of charcoal rot caused by Macrophomina phaseolina in rabis orghum. Phytoparasitica., 36 (2): 199-208.

Edmunds, L. K., 1964, Combined relation of plant maturity, temperature and soil moisture to charcoal rot development in grain sorghum. Phytopathology, 54: 
514-517.

Gill, S. S., Khan, N. A., Anjum, N. A. and Tuteja, N., 2005, Amelioration of cadmium stress in crop plants by nutrients management: Morphological, physiological and biochemical aspects. Plant Stress J., 42 (1): 1-9.

Girish, G., Ashok, B., Muniswamy, S., Jayalakshmi, S. K. and Patil, J. R., 2016, Genetic variability and character association studies for root traits and charcoal rot disease in sorghum, Proc. Natl. Acad. Sci., India, Sect. Biol. Sci., 22-28.

Harleen, K, Sharma, S. and Saxena, A. K., 2008, Biochemical indicators for resistance to charcoal and fusarium stalk-rot in maize hybrids, J. Res. Punjab Agric. Univ., 45 (3 \& 4): 11720.

Iyanar, K., Vijayakumar, G. and Khan, A. K. F. 2010, Correlation and path analysis in multicut fodder sorghum. Electronic J. Pl. Breed., 1 (4): 1006-1009.

Johanson, H. W., Robinson, H. F. and Comstock, R. S., 1955, Estimates of genetic and environmental variability in soybean. Agron. J., 47: 314-318.

Kalpande, V. V, Khade, P. A., Ghorade, R. B., Dange, A. M. and Thawari, S. B. 2015. Genetic variability, heritability and genetic advance for seed quality parameters in some of the land races of sorghum. The Bioscan, 10(2): 719-721.

Mahajan, R. C., Wadikar, P. B., Pole, S. P. and Dhuppe, M. V., 2011, Variability, correlation and path analysis studies in sorghum. Res. J. Agric. Sci., 2 (1): 101103.

Mughogho, L. K. and Pande, S., 1984, Charcoal rot of sorghum.In: Sorghum Root and Stalk Rots, A critical Review: Proc. of the Consultative Group Discussion of Research Needs and Strategies for Control of Sorghum Root and Stalk Rot Diseases, Bellagio, Italy, pp. 10-23.

Patil, A. M., 2009, Genome-wide molecular mapping, introgression of stable QTLs and expressional quantitation of transcription factor genes in charcoal rot manifestation in Sorghum bicolor (L.) Moench, Ph. D. Thesis, Univ. Agric. Sci. Dharwad, Karnataka (India).

Sankarapandian, R., Subbaraman, N. and Amirthadevarathinam, A., 1994, Heterosis in grain sorghum. Madras Agric. J., 81 (1): 1-2.

Scapim, C. A., Rodrigues, J. A. S., Cruz, C. D., Gomes, J. A. and Braccini, L. A., 1998, Gene effects, heterosis and inbreeding depression for grain sorghum characters. Perquisa Agropecuaria Brasileira., 33: 18471857.

Thombre, M.V and Patil, R.C. 1985. Interrelationship between yield and some agronomic characters in a $4 \times 5$ (line $\times$ tester) set of sorghum. Curr. Res. Rep., 1: 68-73.

\section{How to cite this article:}

Nagamani, V. and Biradar, B.D. 2018. Genetic Studies on Charcoal Rot Resistance in Minicore Collection of Sorghum during Rabi Season. Int.J.Curr.Microbiol.App.Sci. 7(03): 979-987. doi: https://doi.org/10.20546/ijcmas.2018.703.116 